\title{
Structure and dendroecology of Thuja occidentalis in disjunct stands south of its contiguous range in the central Appalachian Mountains, USA
}

\author{
Joshua A. Kincaid
}

\begin{abstract}
Background: Information on forest structure, growth, and disturbance history is essential for effective forest management in a dynamic landscape. Because most of our research concerning the ecology and growth of Thuja occidentalis comes from sites in northern portions of its range, highly contextual biotic and abiotic factors that affect the species in more southern locales may not be fully accounted for. This research characterized the structural attributes and growth dynamics of Thuja occidentalis in disjunct forest stands south of its contiguous range margin.

Methods: The Thuja occidentalis forests examined in this research were located in the central Appalachian Mountains, USA, approximately $440 \mathrm{~km}$ south of the contiguous range margin of the species. Forest structural attributes were characterized in two Thuja occidentalis forest stands, which are rare in the region. Tree-ring chronologies were used to examine the influences of disturbance and climate on the growth of Thuja occidentalis.

Results: The forests contained a total of 13 tree species with Thuja occidentalis contributing substantially to the basal area of the sites. Thuja occidentalis stems were absent in the smallest size class, while hardwood species were abundant in the smallest classes. Thuja occidentalis stems also were absent from the $<70$ years age class. By contrast, Thuja occidentalis snags were abundant within stands. Growth-release events were distributed across the disturbance chronology and generally affected a small number of trees. The Thuja occidentalis tree-ring chronology possessed an interseries correlation of 0.62 and mean sensitivity of 0.25 . The correlation between mean temperature and Thuja occidentalis growth was weak and variable. Growth and moisture variables were more strongly correlated, and this relationship was predominantly positive.

Conclusions: Structural attributes indicate the forests are in the understory reinitiation stage of forest development. Silvicultural manipulations may be necessary to promote Thuja occidentalis establishment. The sensitivity of Thuja occidentalis to climate appears similar throughout its range, but geographical variation in the growth response to climate factors is apparent. More research is necessary to expand the geographical and ecological scope of our knowledge concerning Thuja occidentalis, particularly at more southern and disjunct sites.
\end{abstract}

Keywords: Northern white cedar, Disturbance, Climate, Range, Disjunct, Radial growth, Regeneration

Correspondence: jkincaid@su.edu

Shenandoah University, 1460 University Drive, Winchester, VA 22601, USA 


\section{Background}

Information on stand structure, growth, and disturbance history is essential to our understanding of patterns and processes in forest ecosystems. By examining the structural attributes and radial growth patterns of trees, we can quantitatively characterize conditions that have influenced forest stand development (Lorimer 1980; Frelich and Lorimer 1991; Hart and GrissinoMayer 2008; Hart et al. 2012). The range of variation elucidated by quantitative data facilitates more effective forest management in a landscape affected by both anthropogenic activities and climate change (Kincaid and Parker 2008; Hart et al. 2010; Hart et al. 2012). Climate change is expected to greatly reduce suitable habitat for many tree species in eastern North America. Climate coupled with factors such as disturbance and competition can affect the physiology and growth of trees, including processes such as regeneration and recruitment (Paul et al. 2014). Under various climate change scenarios, one of the most impacted tree species will be northern white cedar (Thuja occidentalis L.) (Iverson et al. 2008).

T. occidentalis, also known as arborvitae, is a shadetolerant coniferous tree species of eastern North America. This slowing growing tree commonly reaches heights of $12-15 \mathrm{~m}$ and diameters ranging from 30 to $60 \mathrm{~cm}$ (Johnston 1990). Although individuals exceeding 1000 years of age have been documented in Canada, the typical lifespan for T. occidentalis is 80-400 years (Larson 2001). The species tolerates a range of substrates, but growth is maximized on moist, well-drained soils derived from calcareous bedrock (Johnston 1990). T. occidentalis occurs in mixed to pure stands throughout its contiguous range, which extends across southeastern Canada and the northeastern United States. Isolated, disjunct stands exist beyond the contiguous range margin as far south as North Carolina and Tennessee (Braun 1950; Caplenor and Speir 1975; Walker 1987), but are rare in the central Appalachian Mountains (Fleming 1999; Fleming and Coulling 2001).

It is a common assumption that environmental conditions experienced by marginal or disjunct populations are more stressful or different than those experienced by core populations (Lesica and Allendorf 1995; Hardie and Hutchings 2010; Hart et al. 2010). If marginal populations are adapted to more stressful or different biotic and abiotic conditions, they may have high conservation value as evolutionary legacies or components of biodiversity (Hoffmann and Blows 1994; Allendorf et al. 1997; Hardie and Hutchings 2010). Several studies have examined $T$. occidentalis forest structure and growth in northern portions of the range, including in disjunct populations (e.g. Kelly et al. 1994; Tardif and Stevenson 2001; Kipfmueller et al. 2010; Grotte et al. 2012; Ruel et al. 2014). However, research examining T. occidentalis forests south of their contiguous range margin has been limited to examinations of ecological community characteristics and population genetics (Walker 1987; Young 1996; Fleming 1999; Fleming and Coulling 2001).

The overall goal of this research was to document the structural attributes and radial growth dynamics of T. occidentalis in disjunct stands south of its contiguous range margin. There were three specific objectives for this research: 1) to quantify stand structural attributes; 2) to reconstruct the history of $T$. occidentalis growth-release events; and 3) to characterize the relationship between $T$. occidentals radial growth and climate.

\section{Study area}

This study was conducted in Rockingham County, Virginia (38.6363 N, -78.8502 W) located in the northern Shenandoah Valley, USA (Fig. 1). Rockingham County lies within the Ridge and Valley Physiographic Province, which is characterized by long, linear ridges separated by valleys with a trellis drainage pattern. Bedrock consists of Paleozoic sedimentary rocks (Fenneman 1938). Mean total precipitation in the study area is $852 \mathrm{~mm}, 61 \%$ of which occurs during the months of May through October. The mean annual temperature is $13{ }^{\circ} \mathrm{C}$ (SERCC 2016).

Braun (1950) classified the study area as part of the Ridge and Valley Section of the Oak-Chestnut Forest Region, but the area is a transitional zone with elements of the mixed mesophytic and oak-chestnut regions. More recently the area was classified as the Appalachian Oak Section of the Mesophytic Forest Region with indicator species including Quercus alba, Quercus prinus, Liriodendron tulipifera and Pinus virginiana (Dyer 2006). T. occidentalis forest stands in the region are typically small ( $\sim 0.1$ to $1.0 \mathrm{ha})$, isolated, and extremely rare. In Virginia, T. occidentalis forests tend to be confined to north-facing slopes and cliffs with calcareous bedrock (Fleming 1999; Fleming and Coulling 2001). The disjunct $T$. occidentalis stands examined in this research are located approximately $440 \mathrm{~km}$ south of the contiguous range margin.

\section{Methods}

Structural attributes were obtained from 100.01 ha circular plots in each of two $T$. occidentalis forest stands ( $n=20$ plots). Plot centroids were established every $10 \mathrm{~m}$ along a randomly placed transect in each stand. Each transect was situated at the mid-slope position and parallel to slope contours to avoid forest and environmental transitions. Two transects were adequate for data collection because both stands were oblong in extent and located on steep slopes. In each plot, species, diameter at breast height $(\mathrm{dbh}=1.4 \mathrm{~m})$ of all stems $\geq$ $2.5 \mathrm{~cm} \mathrm{dbh}$, and snag abundance were recorded. The 

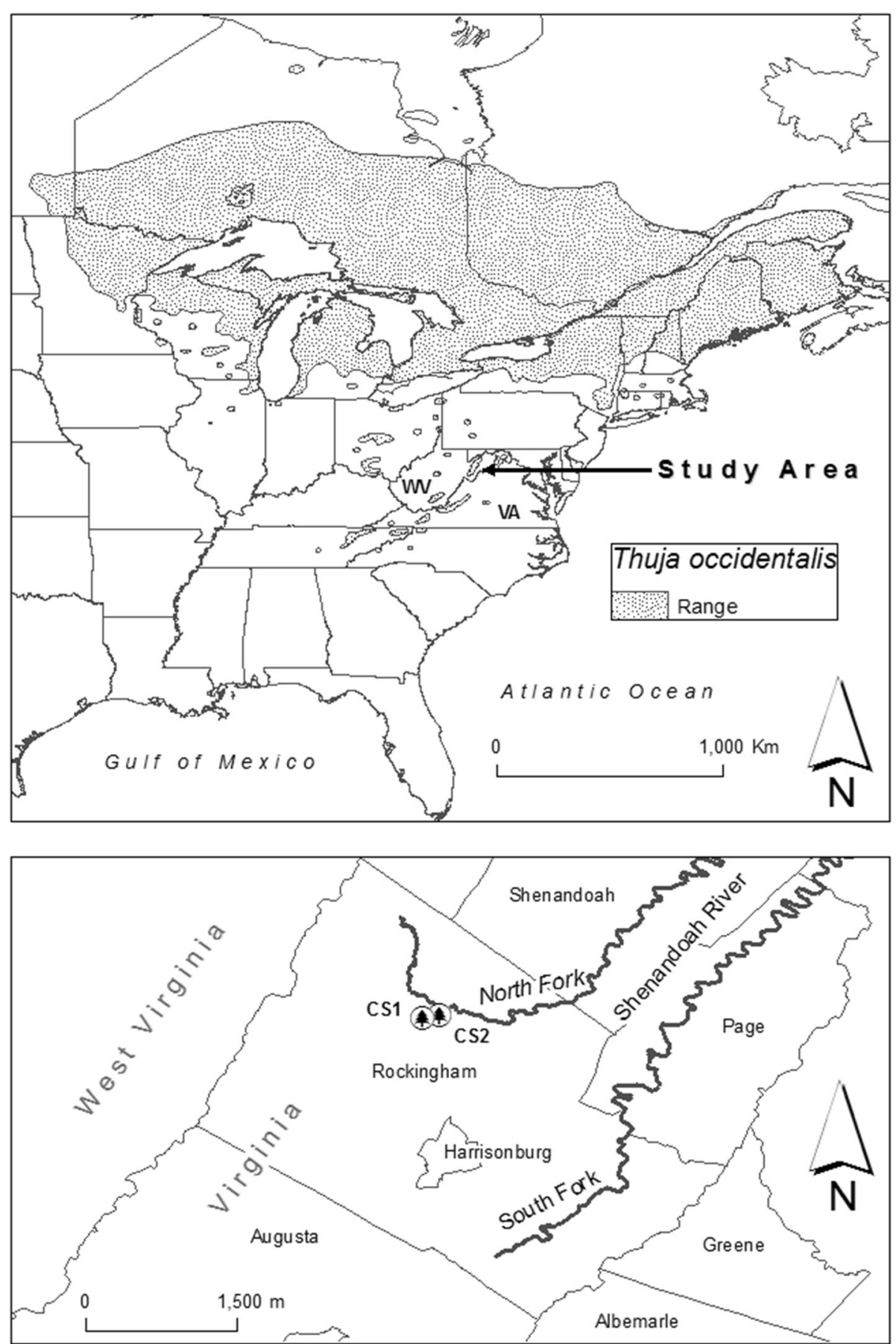

Fig. 1 Map showing the range of Thuja occidentalis and study area (see Additional file 1 for high resolution)

point-quarter method was used at plot centroids to systematically select canopy trees for the collection of increment cores (Cottam and Curtis 1956). In some cases steep terrain restricted sampling to trees that could be safely cored at breast height. A total of 42 trees were examined in this research.

In the laboratory, all increment cores were air-dried, glued to wood mounts, and sanded with progressively finer grits of sand paper (Phipps 1985; Stokes and Smiley 1996). The growth rings on all cores were visually inspected and crossdated using the list method (Yamaguchi 1991). Ringwidths were measured to the nearest $0.001 \mathrm{~mm}$ using a Velmex measuring stage and Measure J2X software. The visually crossdated measurement series were statistically verified using the computer program COFECHA (Holmes 1983; Grissino-Mayer 2001). 
I used standard dendroecological techniques to reconstruct the history of $T$. occidentalis growth-release events in each stand (Lorimer and Frelich 1989; Nowacki and Abrams 1997; Rubino and McCarthy 2004). Raw tree-ring measurements were analyzed using a 10-year running median and percent-increase equation (Nowacki and Abrams 1997; Rubino and McCarthy 2004). Minor release events were defined as median growth increases between $25 \%$ and $49.9 \%$. Major releases were defined as median growth increases of $\geq 50 \%$. The temporal distribution of growthrelease events detected using the $\geq 50 \%$ growth threshold was not significantly different $(t=1.36 ; p=0.20)$ than the distribution observed using the absolute increase threshold $(\geq 0.41 \mathrm{~mm})$ of Fraver and White (2005). Only growth-release events sustained for a minimum of 3 years were recorded in this research (Rubino and McCarthy 2004). The growth-release data were used to construct a decadal disturbance chronology detailing the history of $T$. occidentalis growth-release events in each stand.

In preparation for the analysis of $T$. occidentalis growth-climate interactions, I used the computer program ARSTAN to standardize the raw tree-ring measurements with a 30-year cubic smoothing spline. Standardization removes the effects of tree age and forest disturbance and allows for the comparison of trees with different growth rates (Cook 1985). Pearson correlation analysis was used to examine the relationship between climate and the T. occidentalis standard chronology. Climate data for Virginia Climate Division 5 were retrieved from the National Climate Data Center (NCDC 2015). Division 5 data were interpolated from stations using a $5 \mathrm{~km}$ grid resolution to ensure adequate spatial sampling. The climate variables examined in this research included monthly mean temperature, monthly total precipitation, and monthly Palmer Drought Severity Index (PDSI) for the current and previous year. The PDSI is commonly used in climate-tree growth research because it integrates measures of soil water, precipitation, and temperature, and more closely reflects the conditions required for tree growth than a single variable alone (Henderson and Grissino-Mayer 2009). The T. occidentalis radial growthclimate relationship was analyzed using a 17-month window extending from 1895-2010.

\section{Results}

\section{Forest structural attributes}

The T. occidentalis forest stands contained a total of 13 tree species with a mean stand density of $915 \pm 219.2$ stems/ha (Table 1). Total stand basal area averaged 54.3 $\pm 12.4 \mathrm{~m}^{2} /$ ha with $T$. occidentalis contributing substantially to the basal area of the sites. The importance values for T. occidentalis at CS1 and CS2 were $82.2 \%$ and $52.5 \%$, respectively. Tilia americana comprised a distinct second tier at CS2 where the relative dominance
Table 1 Compositional characteristics by forest stand

\begin{tabular}{|c|c|c|c|c|}
\hline Site & Species & $D$ & BA & IV \\
\hline \multirow[t]{8}{*}{$\mathrm{CS1}$} & Thuja occidentalis L. & 830 & 54.8 & 82.2 \\
\hline & Quercus muehlenbergi Engelm. & 40 & 0.5 & 2.3 \\
\hline & Liriodendron tulipifera $\mathrm{L}$. & 40 & 3.6 & 4.7 \\
\hline & Ostrya virginiana (Mill.) K. Koch & 50 & 0.2 & 2.5 \\
\hline & Cercis canadensis L. & 20 & 0.1 & 1.0 \\
\hline & Acer saccharum Marshall & 10 & 0.5 & 0.9 \\
\hline & Pinus strobus L. & 50 & 2.3 & 4.2 \\
\hline & Fraxinus americana $\mathrm{L}$. & 30 & 1.1 & 2.3 \\
\hline \multirow[t]{10}{*}{ CS2 } & Thuja occidentalis L. & 310 & 29.2 & 52.5 \\
\hline & Tilia americana L. & 60 & 9.9 & 14.8 \\
\hline & Cercis canadensis L. & 110 & 0.2 & 7.5 \\
\hline & Ostrya virginiana (Mill.) K. Koch & 140 & 1.5 & 10.9 \\
\hline & Cornus florida L. & 10 & 0 & 0.7 \\
\hline & Hamamelis virginiana $\mathrm{L}$. & 20 & 0 & 1.3 \\
\hline & Ailanthus altissima (Mill.) Swingle & 20 & 1.9 & 3.3 \\
\hline & Juglans nigra L. & 10 & 0 & 0.7 \\
\hline & Acer saccharum Marshall & 20 & 0.9 & 2.3 \\
\hline & Fraxinus americana $\mathrm{L}$. & 60 & 1.9 & 6.0 \\
\hline
\end{tabular}

Columns refer to density $(D$, stems $/ \mathrm{ha})$, basal area $\left(\mathrm{BA}, \mathrm{m}^{2} / \mathrm{ha}\right)$, and importance value [IV $=($ relative density + relative basal area $) / 2]$

of the species was $21.7 \%$. Species of tertiary importance at CS1 and CS2 included Liriodendron tulipifera, Fraxinus americana, Ailanthus altissima and Pinus strobus.

The size distribution of stems within the stands varied from unimodal or bimodal to multimodal structures (Fig. 2). At CS1 the size distribution approximated a unimodal structure with the number of $T$. occidentalis stems peaking in the $20-25 \mathrm{~cm}$ size class. No $T$. occidentalis stems were present in the smallest size class. L. tulipifera, $P$. strobus, and the "other hardwood" group exhibited a bimodal structure of stems at CS1. F. americana occupied the intermediate size classes from $10-30 \mathrm{~cm}$ at both sites. The size distribution of $T$. americana was distinctly multimodal, while $A$. altissima exhibited a bimodal distribution of stems at CS2. T. occidentalis peaked in the largest size class at CS2, but was absent from the smallest class. The number of "other hardwood" stems was greatest in the smallest size classes at both sites.

The absence of $T$. occidentalis stems in the smallest size class at both sites was reflected in the age distribution of the species. The number of T. occidentalis stems peaked in the 90-110 year age-classes, while stems less than 70 years old were absent from the stands. Aside from sapling snags, there was no evidence of recent $T$. occidentalis establishment and recruitment in the understories of CS1 or CS2 (Fig. 3). 


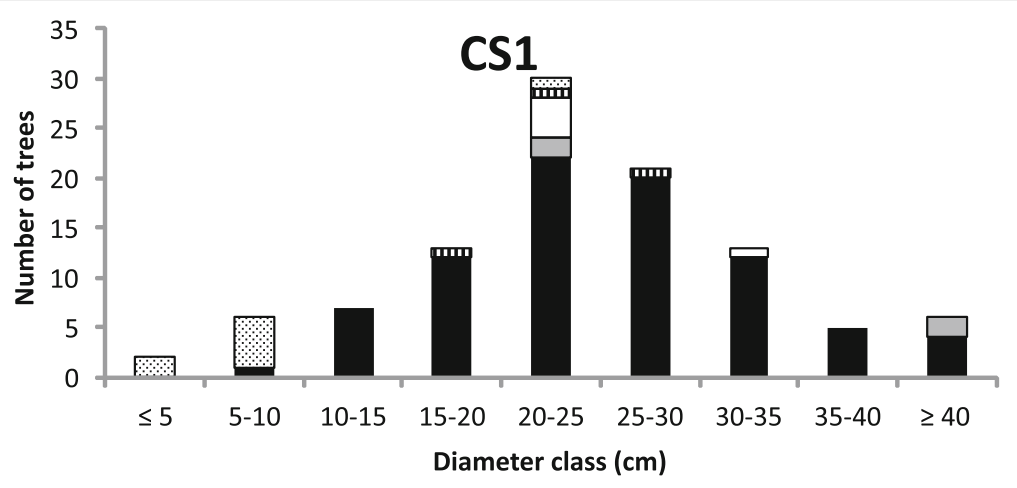

- Thuja occidentalis $\mathbf{\square}$ Liriodendron tulipifera $\boldsymbol{\square}$ Pinus strobus

m Fraxinus americana Other hardwoods

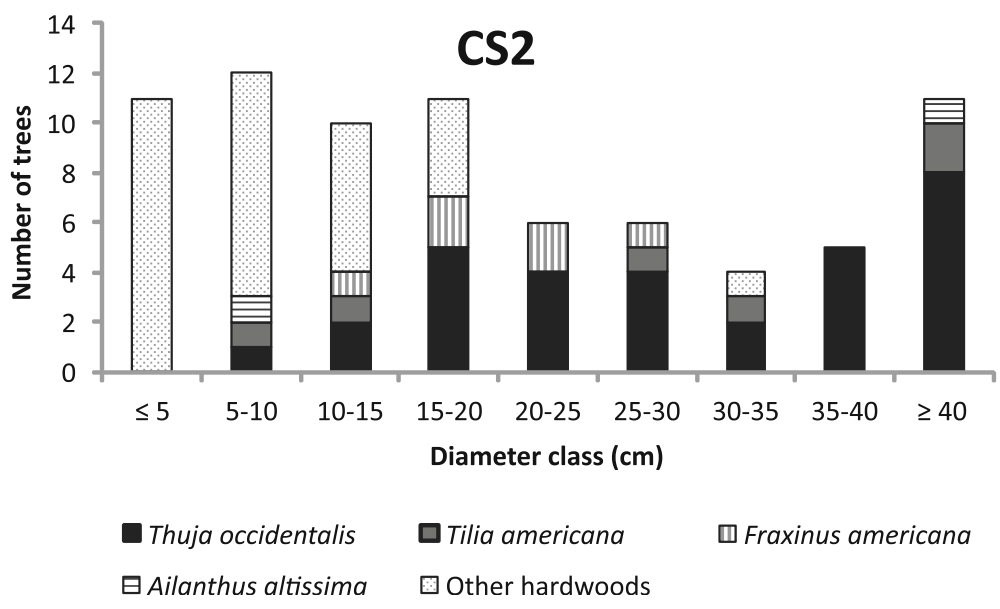

Fig. 2 Diameter class distributions for tree species in each forest stand. Note that $y$-scale varies (see Additional file 1 for high resolution)

A total of 57 snags representing four different species were identified in this research (Table 2; Fig. 4). Seven percent of the snags $(n=4)$ were identified only as "hardwood." Mean snag dbh for all stems was $11.3 \pm$ $4.0 \mathrm{~cm}$ with a maximum of $36.5 \mathrm{~cm}$ for a single Tsuga canadensis stem. Total snag density averaged $280 \pm 212.1$ stems/ha within stands. The basal area of all snags was

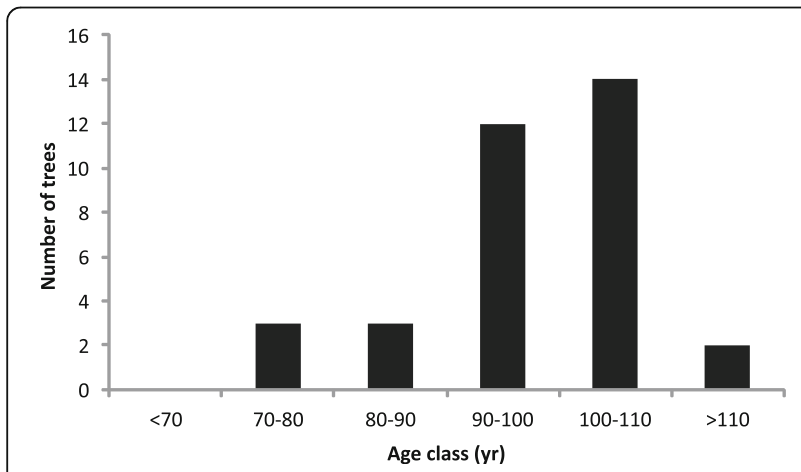

Fig. 3 Age class distribution of Thuja occidentalis in the study area (see Additional file 1 for high resolution) similar ( $\sim 3.0 \mathrm{~m}^{2} /$ ha) for both stands. T. occidentalis represented $71.9 \%$ of all snags, but $T$. canadensis snags were dominant (76.9 \% of snags) at CS2.

\section{Radial growth-release events}

Of the $42 T$. occidentalis individuals examined in this research, $59.5 \%(n=25)$ experienced growth release events (Fig. 5). All 25 of these trees exhibited at least one growth increase between $25 \%$ and $49.9 \%$ over the 10-year running median. Major events resulting in a $\geq 50 \%$ growth increase were detected in $28.6 \%(n=12)$ of the trees. One T. occidentalis individual experienced four minor release

Table 2 Snag characteristics by forest stand. Columns refer to density ( $D$, stems/ha) and basal area (BA, $\mathrm{m}^{2} / \mathrm{ha}$ )

\begin{tabular}{llll}
\hline Site & Species & D & BA \\
\hline CS1 & Thuja occidentalis L. & 380 & 2.63 \\
& Pinus strobus L. & 10 & 0.27 \\
& Hardwood & 40 & 0.06 \\
CS2 & Thuja occidentalis L. & 30 & 0.45 \\
& Tsuga canadensis (L.) Carr. & 100 & 2.51 \\
\hline
\end{tabular}



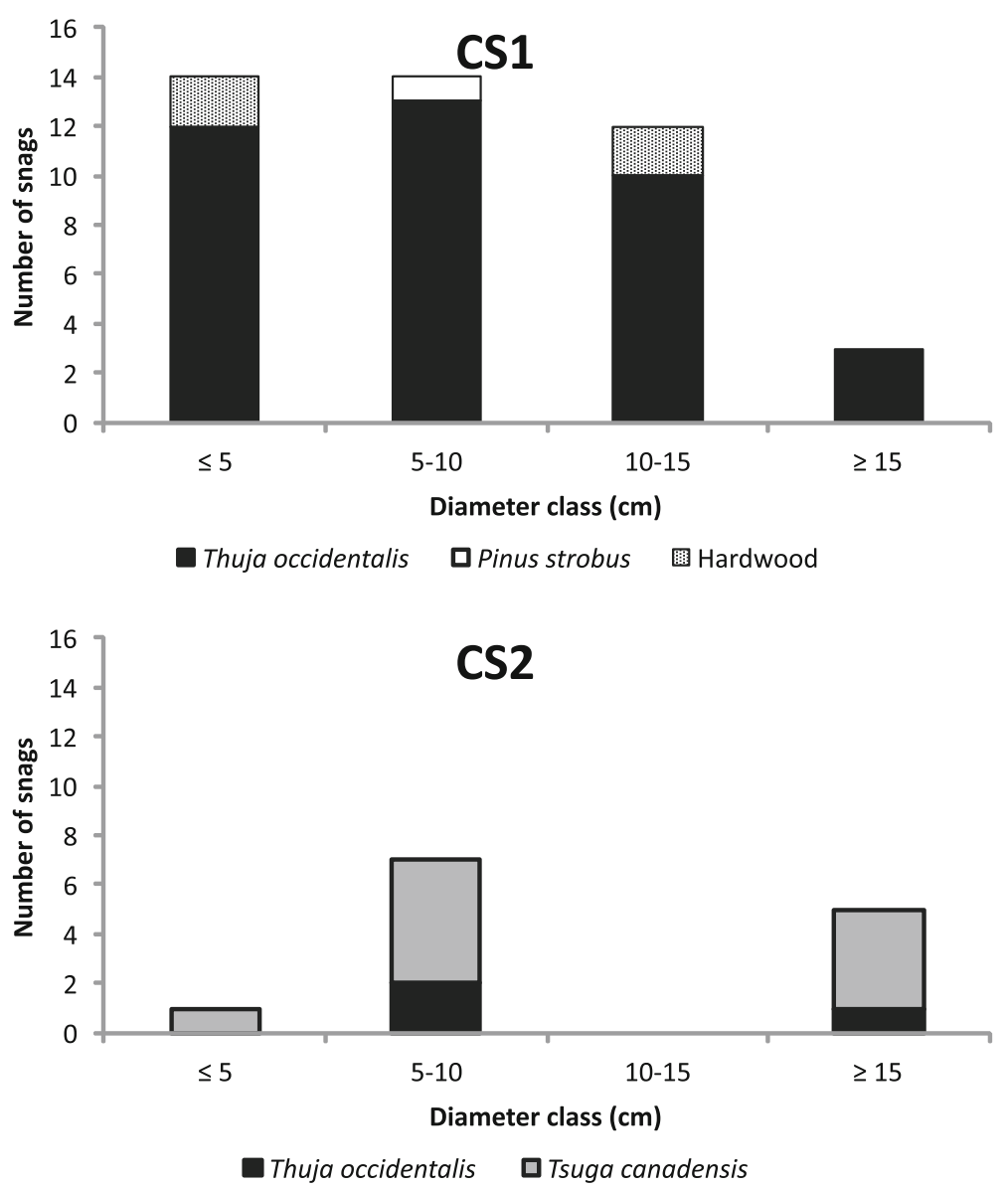

Fig. 4 Diameter class distributions for snags in each forest stand (see Additional file 1 for high resolution)

events, while an additional five individuals experienced 2 to 3 minor growth release events. Only three individuals experienced a growth increase $\geq 100 \%$ over the 10 -year running median, with the increase in one tree peaking at $165.3 \%$. Growth release events were generally distributed across the chronology, but there was a conspicuous increase in major events during the 1950s and 1960s. The mean release duration was $7.1 \pm 1.0$ years.

\section{Radial growth-climate interactions}

The $42 \mathrm{~T}$. occidentalis measurement series composing the chronology possessed an interseries correlation of $0.62(p<0.01)$ and mean sensitivity of 0.25 . Mean sensitivity is a measure of the year-to-year variability in tree-ring widths and is a standard COFECHA metric (Speer 2010). Sustained periods of above mean radial growth occurred during the 1940s and late 1960s to mid-1970s. Notable peaks in mean growth occurred in 1906 and 1995. Prolonged periods of below mean radial growth occurred in the late 1910s to mid-1920s and late 1940s to late 1950s.

Examination of the standard chronology revealed significant correlations $(p<0.05)$ between T. occidentalis radial growth and climate variables (Fig. 6). The relationship between mean temperature and $T$. occidentalis growth was the weakest among all climate variables examined in this research. Only previous August (+) and current July (-) mean temperature were significantly correlated with $T$. occidentalis growth. The relationship between $T$. occidentalis growth and precipitation was predominantly positive, with previous October, current June and August-September precipitation being significantly correlated with the chronology. The positive correlation between $T$. occidentalis growth and PDSI was generally stronger and more persistent than the association between growth and temperature or precipitation alone.

\section{Discussion}

\section{Forest structures and dynamics}

T. occidentalis was the leading canopy dominant at CS1 and CS2, but was not well-represented in the smallest size classes. The age distribution of T. occidentalis indicated a wave of establishment between 1900 and 1920, with successful recruitment lacking after 1940. Heitzman et al. (1997) documented a comparable timeline of T. occidentalis establishment and recruitment in Michigan, which they ascribed to stand initiating disturbances between 1870 and 1935, followed by stem exclusion in the 


\section{Minor release}
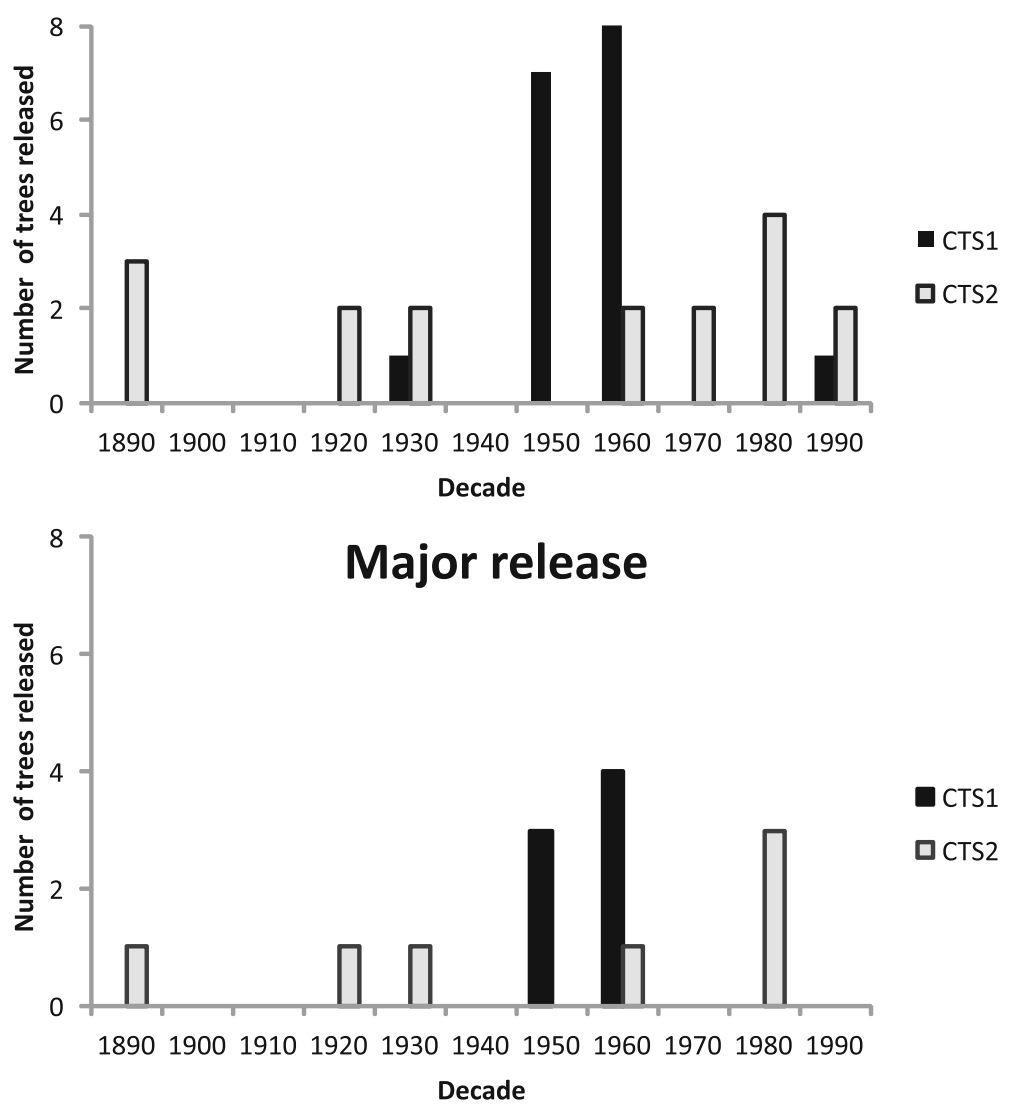

CTS1

口CTS2

Fig. 5 Disturbance chronologies for Thuja occidentalis in each forest stand. Minor releases are events eliciting median growth increases between 25 and $49.9 \%$. Major releases are events eliciting median growth increases of $\geq 50 \%$ (see Additional file 1 for high resolution)

1940s. The abundance of snags, indicative of self-thinning in the past, and the presence of hardwood species in the smallest size classes suggests CS1 and CS2 are in the early phases of the understory reinitiation stage during which herbs, shrubs, and advance regeneration invade the forest (Oliver and Larson 1996). As the understory reinitiation stage progresses, stand densities should decline to levels at which the regeneration of $T$. occidentalis is more likely to occur (Lamy et al. 1999).

The presence of $A$. altissima in the understory and overstory at CS2 is cause for concern. A. altissima is an introduced species from China that frequently spreads into forests by aggressively colonizing canopy gaps (Knapp and Canham 2000; Espenschied-Reilly and Runkle 2008; Martin et al. 2010). In addition to outcompeting native species in canopy gaps, A. altissima is associated with changes in ecosystem processes and soil nutrient cycling, which may change the relative abundance of native trees to favor other, more competitive species (Gomez-Aparicio and Canham 2008). Using herbicides to control $A$. altissima is probably the most effective approach at this time, although landowners with limited budgets can remove the species with physical approaches such as pulling, cutting, digging, or girdling (Virginia 2009).

\section{Disturbance and radial growth}

T. occidentalis growth-release events were distributed across the disturbance chronology and generally affected a small number of trees, which is characteristic of forest gap dynamics. Canopy gap-scale processes involving the death of a tree or group of trees are often necessary for the persistence of shade tolerant tree species in forests (Runkle and Yetter 1987; Runkle 1998; Frelich 2002; Kincaid 2012). Increased light availability has been reported to enhance $T$. occidentalis seedling survival and abundance in northern portions of the range (Cornett et al. 2000; Rooney et al. 2002). Moreover, Scott and Murphy (1987) observed most T. occidentalis regeneration in their study area in Michigan was associated with a large patch of windthrown trees, not small, single-tree gaps. Despite evidence of ongoing canopy gap-scale processes within the forest stands, both structural attributes and field observations suggested a lack of successful $T$. 

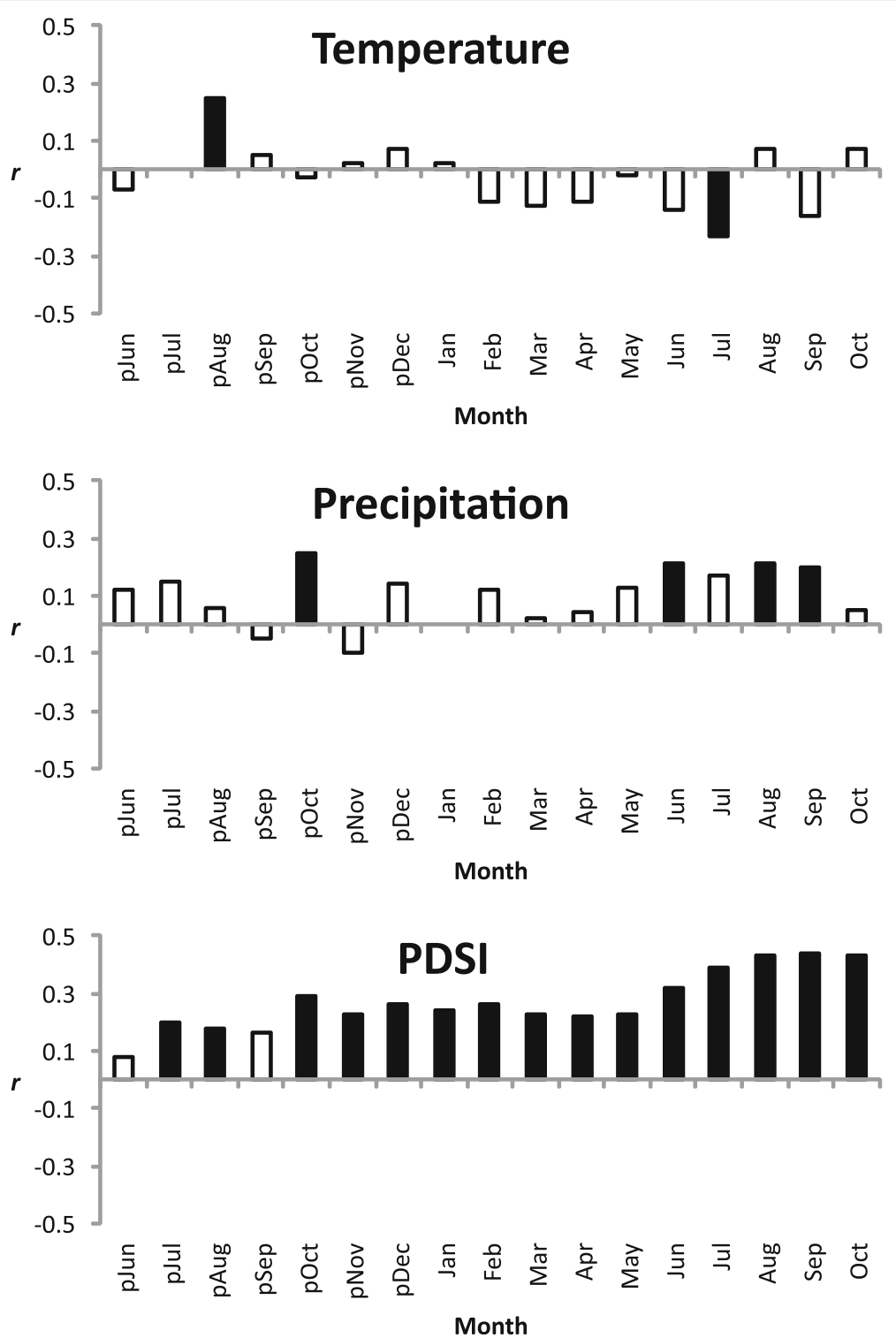

Fig. 6 Correlation between the standardized tree-ring chronology and climate variables. Solid bars indicate significant values $(p<0.05)($ see Additional file 1 for high resolution)

occidentalis establishment during the last 70 years. This research was limited to the examination of radial growth-release events and stand structures, but I speculate single tree gaps are insufficient for $T$. occidentalis regeneration because adjacent canopy trees rapidly expand to occupy the space (Oliver and Larson 1996).

\section{Climate and radial growth}

The interseries correlation for all $42 T$. occidentalis measurement series was statistically significant and compared well with the coefficient (0.66 versus $0.62, p<0.01$ ) reported by Kipfmueller et al. (2010) for a chronology developed in Minnesota, USA. Mean sensitivity of the $T$. occidentalis chronology also was within the range of variation reported for other chronologies developed in northern portions of the range (Kelly et al. 1994; Tardif and Bergeron 1997; Tardif and Stevenson 2001; Kipfmueller et al. 2010). The mean sensitivity of the chronology was nearly identical $(0.25$ versus 0.24$)$ to the sensitivity of another disjunct shade tolerant conifer at its southern range margin in the Appalachian Mountains, USA (Hart et al. 2010). Although the sensitivity of $T$. occidentalis to climate is similar throughout its range, there appears to be geographical variation in the growth response of the species to climate factors such as temperature and precipitation, a phenomenon also observed in other tree species (Cook and Cole 1991; Hart et al. 2010). 
In northern portions of the range, $T$. occidentalis radial growth is inversely related to previous summer temperatures (Kelly et al. 1994; Tardif and Bergeron 1997; Tardif and Stevenson 2001; Kipfmueller et al. 2010). The current study found a positive association between previous August mean temperature and $T$. occidentalis growth. The positive relationship between previous summer temperatures and growth has been observed in other conifers, including Chamaecyparis thyoides L. (Atlantic white cedar) (Hopton and Pederson 2003; Henderson and Grissino-Mayer 2009). Moderate temperatures and abundant precipitation late in the growing season may be favorable for $T$. occidentalis growth in the central Appalachian Mountains; however, the association between growth and temperature is not constant throughout the year. The temperature-growth association turns negative during the spring and summer of the current year, which is a period of phloem expansion in $T$. occidentalis (Bannan 1955). Phloem tissue is essential for the translocation of photosynthates from leaves to other parts of the tree. An inverse growth response to summer temperatures is common in trees because higher temperatures tend to facilitate internal water deficits and increased respiration over carbon fixation (Edwards and Dixon 1995; Henderson and Grissino-Mayer 2009). Although some researchers have suggested $T$. occidentalis growth is not limited by climate, particularly by temperature in northern portions of the range, climate could influence the regeneration and growth of the species (Tardif and Stevenson 2001; Paul et al. 2014) in disjunct stands south of the contiguous range margin.

In contrast to the relationship between $T$. occidentalis radial growth and temperature, the relationship between radial growth and moisture variables was more consistently positive. The positive associations between spring and summer precipitation of the current year and $T$. occidentalis growth are consistent with relationships reported in northern portions of the range, including the northwestern range margin (Tardif and Stevenson 2001; Kipfmueller et al. 2010). The significant positive association between previous October precipitation and T. occidentalis growth is unique to this study. Hart et al. (2010) found a positive association between precipitation in October of the previous year and the growth of $T$. canadensis in disjunct stands near its southern range margin in the Appalachian Mountains. The authors speculated that October precipitation influences autumn phenology. It also is possible precipitation during the fall of the previous year facilitates ongoing carbohydrate storage, which is necessary for renewed growth in the following spring (Henderson and Grissino-Mayer 2009). The consistently positive association between $T$. occidentalis growth and PDSI has been observed in other southern conifers and is at least partly the result of autocorrelation in the index because values from previous months are used to calculate current values (Grissino-Mayer and Butler 1993; Henderson and Grissino-Mayer 2009; Hart et al. 2010). Despite the autocorrelation in the index values, the positive relationship between PDSI and $T$. occidentalis growth may reflect the sensitivity of the species to moisture conditions in disjunct stands south of its contiguous range margin. The positive association between growth and PDSI is particularly strong from late summer to fall of the current year, which indicates that moisture conditions during this period are important to the growth of $T$. occidentalis in the study area.

\section{Conclusion}

This research has characterized the structural attributes and radial growth dynamics of disjunct $T$. occidentalis forests in the central Appalachian Mountains, USA. Structural attributes indicate the forest stands are in the understory reinitiation stage of forest development (Oliver and Larson 1996). Silvicultural manipulations such as thinning may be necessary to stimulate the understory and promote $T$. occidentalis establishment. It also may be necessary to utilize chemical and physical approaches to reduce $A$. altissima in order to prevent the species from colonizing canopy gaps and outcompeting native species such as $T$. occidentalis (Knapp and Canham 2000; Espenschied-Reilly and Runkle 2008; Virginia 2009; Martin et al. 2010).

The sensitivity of $T$. occidentalis radial growth to climate appears similar throughout its range, including at disjunct sites beyond its contiguous range margin. However, geographical variation in the growth response of the species to climate factors is apparent (Cook and Cole 1991; Hart et al. 2010). The response of T. occidentalis growth to moisture conditions is predominately positive throughout the year, while the relationship between growth and temperature is much more irregular.

The current study has documented geographical variation in the growth of $T$. occidentalis in disjunct forest stands south of its contiguous range margin. Most studies examining $T$. occidentalis ecology and growth come from northern portions of the range, so more research is necessary to increase the geographical and ecological scope of our knowledge, particularly at more southern and disjunct sites. Indeed, current research could be overlooking important local or regional biotic and abiotic factors that can significantly affect $T$. occidentalis ecology and growth.

\section{Additional file}

Additional file 1: All figures in high resolution. (ZIP $3.57 \mathrm{mb}$ ) 


\section{Acknowledgements}

I would like to thank Gary Fleming and Wendy Hochstedler for information regarding the white cedar forests in this study. I also thank Angela Felicio, Cory Miller, and Kirby Talbert for assistance in the field and laboratory. This manuscript was improved by comments from Doug Enders and two anonymous reviewers.

\section{Author's contribution}

Joshua Kincaid is the sole author of this manuscript.

\section{Author's information}

Joshua Kincaid, Ph.D. Associate Professor of Environmental Studies and Geography, Shenandoah University. Background: Ecological biogeography, dendroecology, and human-environment relationships

\section{Competing interests}

There are no financial or non-financial competing interests with regard to this manuscript.

\section{Received: 12 August 2016 Accepted: 1 November 2016} Published online: 11 November 2016

\section{References}

Allendorf FW, Bayles D, Bottom DL, Currens KP, Frissell CA, Hankin D, Lichatowich JA, Nehlsen W, Trotter PC, Williams TH (1997) Prioritizing pacific salmon stocks for conservation. Conserv Biol 11:140-152

Bannan MW (1955) The vascular cambium and radial growth in Thuja occidentalis L. Can J Bot 33:113-138

Braun EL (1950) Deciduous forests of eastern North America. The Blakiston Company, Philadelphia

Caplenor D, Speir H (1975) Thuja occidentalis L. on the Eastern Highland Rim in Tennessee. J Tenn Acad Sci 50:74-75

Cook ER (1985) A time-series analysis approach to tree-ring standardization. PhD Dissertation, University of Arizona

Cook ER, Cole J (1991) On predicting the response of forests in eastern North America to future climate change. Clim Change 19:271-282

Cornett MW, Frelich LE, Puettmann KJ, Reich PB (2000) Conservation implications of browsing by Odocoileus virginianus in remnant upland Thuja occidentalis forests. Biol Conserv 93:359-369

Cottam G, Curtis JT (1956) The use of distance measures in phytosociological sampling. Ecology 37:451-460

Dyer JM (2006) Revisiting the deciduous forests of eastern North America. Bioscience 56:341-352

Edwards DR, Dixon MA (1995) Mechanisms of drought response in Thuja occidentalis L. I. Water stress conditioning and osmotic adjustment. Tree Physiol 15:121-127

Espenschied-Reilly AL, Runkle JR (2008) Distribution and changes in abundance of Ailanthus altissima (Miller) Swingle in a southwest Ohio woodlot. Ohio J Sci 108:16-22

Fenneman NM (1938) Physiography of eastern United States. McGraw-Hill Book Company, New York

Fleming GP (1999) Plant communities of limestone, dolomite, and other calcareous substrates in the George Washington and Jefferson national forests. Virginia Department of Conservation and Recreation, Division of Natural Heritage, Natural Heritage Technical Report 99-4, Virginia

Fleming GP, Coulling PP (2001) Ecological communities of the George Washington and Jefferson national forests. Preliminary classification and description of vegetation types. Virginia Department of Conservation and Recreation, Division of Natural Heritage, Natural Heritage Technical report $01-1$, Virginia

Fraver S, White AS (2005) Identifying growth releases in dendrochronological studies of forest disturbance. Can J For Res 35:1648-1656

Frelich LE, Lorimer CG (1991) Natural disturbance regimes in hemlock-hardwood forests of the upper Great Lakes region. Ecol Monogr 61:145-164

Frelich LE (2002) Forest dynamics and disturbance regimes. Cambridge University Press, Cambridge

Gomez-Aparicio L, Canham CD (2008) Neighborhood analyses of the allelopathic effects of the invasive tree Ailanthus altissima in temperate forests. J Ecol 96:447-458

Grissino-Mayer HD (2001) Evaluating crossdating accuracy: a manual and tutorial for the computer program COFECHA. Tree-Ring Res 57:205-221
Grissino-Mayer HD, Butler DR (1993) Effects of climate on growth of shortleaf pine (Pinus echinata Mill.) in northern Georgia: A dendroclimatic study. Southeast Geogr 33:65-81

Grotte KL, Heinrichs DK, Tardif JC (2012) Old-growth characteristics of disjunct Thuja occidentalis standsat their northwestern distribution limit, central Canada. Nat Area J 32:270-282

Hardie DC, Hutchings JA (2010) Evolutionary ecology at the extremes of species' ranges. Environ Rev 18:1-20

Hart JL, Grissino-Mayer HD (2008) Vegetation patterns and dendroecology of a mixed hardwood forest on the Cumberland Plateau: Implications for stand development. For Ecol Manag 255:1960-1975

Hart JL, van de Gevel SL, Sakulich J, Grissino-Mayer HD (2010) Influence of climate and disturbance on the growth of Tsuga canadensis at its southern limit in eastern North America. Trees 24:621-633

Hart JL, Clark SL, Torreano SJ, Buchanan ML (2012) Composition, structure, and dendroecology of an old growth Quercus forest on the tablelands of the Cumberland Plateau, USA. For Ecol Manag 266:11-24

Heitzman E, Pregitzer KS, Miller RO (1997) Origin and early development of northern white-cedar stands in northern Michigan. Can J For Res 27:1953-1961

Henderson JP, Grissino-Mayer HD (2009) Climate-tree growth relationships of longleaf pine (Pinus palustris Mill.) in the southeastern Coastal Plain, USA. Dendrochronologia 27:31-43

Hoffmann AA, Blows MW (1994) Species borders: Ecological and evolutionary perspectives. Trends Ecol Evol 9:223-227

Holmes RL (1983) A computer-assisted quality control in tree-ring dating and measurement. Tree-Ring Bull 43:69-78

Hopton HM, Pederson N (2003) Climate sensitivity of Atlantic White Cedar at its northern range limit. In: Burke MK, Sheridan P (eds) Atlantic White Cedar: ecology, restoration, and management. Proceedings of the Arlington Echo Symposium, Millersville

Iverson LR, Prasad AM, Matthews SN, Peters M (2008) Estimating potential habitat for 134 eastern UStree species under six climate scenarios. For Ecol Manage 254:390-406

Johnston WF (1990) Thuja occidentalis L. Northern White Cedar. In: Burns RM, Honkala BH (eds) Silvics of North America: Volume 1. Agricultural Handbook 654. USDA Forest Service, Washington DC

Kelly PE, Cook ER, Larson DW (1994) A 1397-year tree-ring chronology of Thuja occidentalis from clifffaces of the Niagara Escarpment, southern Ontario, Canada. Can J For Res 24:1049-1057

Kincaid JA (2012) Regeneration dynamics of Tsuga canadensis in the southern Appalachian Mountains. USA 26:1045-1056

Kincaid JA, Parker AJ (2008) Structural characteristics and canopy dynamics of Tsuga canadensis in forests of the southern Appalachian Mountains, USA. Plant Ecol 199:265-280

Kipfmueller KF, Elliott GP, Larson ER, Salzer MW (2010) An assessment of the dendroclimatic potential of three conifer species in northern Minnesota. Tree-Ring Res 66:113-126

Knapp LB, Canham CD (2000) Invasion of an old-growth forest in New York by Ailanthus altissima: sapling growth and recruitment in canopy gaps. J Torrey Bot Soc 127:307-315

Lamy S, Bouchard A, Simon JP (1999) Genetic structure, variability, and mating system in eastern white cedar (Thuja occidentalis) populations of recent origin in an agricultural landscape in southern Quebec. Can J For Res 29:1383-1392

Larson DW (2001) The paradox of great longevity in a short-lived tree species. Exp Gerontol 36:651-673

Lesica P, Allendorf FW (1995) When are peripheral populations valuable for conservation? Conserv Biol 9:753-760

Lorimer CG (1980) Age structure and disturbance history of a southern Appalachian virgin forest. Ecology 61:1169-1184

Lorimer CG, Frelich LE (1989) A methodology for estimating canopy disturbance frequency and intensity in dense temperate forests. Can J For Res 19:651-663

Martin P, Canham CD, Kobe RK (2010) Divergence from the growth-survival trade-off and extreme high growth rates drive patterns of exotic tree invasions in closed-canopy forests. J Ecol 98:778-789

NCDC (2015) National Climatic Data Center. US Department of Commerce, National Oceanic and Atmospheric Administration, Asheville, http://www. ncdcnoaa.gov. Accessed 15 Jun 2015

Nowacki GJ, Abrams MD (1997) Radial-growth averaging criteria for reconstructing disturbance histories from presettlement-origin oaks. Ecol Monogr 67:225-249 
Oliver CD, Larson BC (1996) Forest stand dynamics. John Wiley \& Sons, New York Paul V, Bergeron Y, Tremblay F (2014) Does climate control the northern range limit of eastern whitecedar (Thuja occidentalis L.)? Plant Ecol 215:181-194

Phipps RL (1985) Collecting, preparing, crossdating, and measuring tree increment cores. US Geological Survey Water Resources Investigations Report 85-4148

Rooney TP, Solheim SL, Waller DM (2002) Factors affecting the regeneration of northern white cedar in lowland of forests of the Upper Great Lakes region, USA. For Ecol Manag 163:119-130

Rubino DL, McCarthy BC (2004) Comparative analysis of dendroecological methods used to assess disturbance events. Dendrochronologia 21:97-115

Ruel JC, Lussier JM, Morissette S, Ricodeau N (2014) Growth response of northern white cedar (Thuja occidentalis) to natural disturbances and partial cuts in mixedwood stands in Quebec, Canada. Forests 5:1194-1211

Runkle JR (1998) Changes in southern Appalachian canopy trees sampled thrice. Ecology 79:1768-1780

Runkle JR, Yetter TC (1987) Treefalls revisited: gap dynamics in the southern Appalachians. Ecology 68:417-424

Scott ML, Murphy PG (1987) Regeneration patterns of northern white-cedar, an old-growth forest dominant. Am Midl Nat 117:10-16

SERCC (2016) The Southeast Regional Climate Center. The University of North Carolina, Chapel Hill, http://www.sercc.com/climate. Accessed 10 Jul 2016

Speer JH (2010) Fundamentals of tree-ring research. University of Arizona Press, Tuscon

Stokes MA, Smiley TL (1996) An introduction to tree-ring dating. University of Arizona Press, Tucson

Tardif J, Bergeron Y (1997) Comparative dendroclimatological analysis of two black ash and two white cedar populations from contrasting sites in the Lake Duparquet region, northwestern Quebec. Can J For Res 27:108-116

Tardif J, Stevenson D (2001) Radial growth-climate association of Thuja occidentalis L. at the northwestern limit of its distribution, Manitoba, Canada. Dendrochronologia 19:179-187

Virginia DOF (2009) Control and utilization of tree-of-heaven. Virginia Department of Forestry, Charlottesville, Available via: www.dof.virginia.gov/infopubs/ Control-And-Utilization-of-TOH-2009-05_pub.pdf

Walker GL (1987) Ecology and population biology of Thuja occidentalis in its southern disjunct range. PhD Dissertation, University of Tennessee

Yamaguchi DK (1991) A simple method for cross-dating increment cores from living trees. Can J For Res 21:414-416

Young $J$ (1996) The cliff ecology and genetic structure of northern white cedar (Thuja occidentalis L.) in its southern disjunct range. MS Thesis, University of Tennessee

\section{Submit your manuscript to a SpringerOpen ${ }^{\circ}$ journal and benefit from:}

- Convenient online submission

- Rigorous peer review

- Immediate publication on acceptance

- Open access: articles freely available online

- High visibility within the field

- Retaining the copyright to your article 